\title{
EVALUATION OF SOIL QUALITY OF A COAL MINE AFFECTED FOREST AT CHANGKI, NAGALAND, INDIA
}

\author{
Khikeya SEMY ${ }^{1^{*}}$, M. R. SINGH ${ }^{1}$, Nishant VATS ${ }^{2}$ \\ ${ }^{1}$ Centre for Biodiversity, Department of Botany, Nagaland University, 798627 Lumami, India \\ ${ }^{2}$ School of Earth, Ocean, and Climate Sciences, Indian Institute of Technology Bhubaneswar, \\ Argul, Jatni, 752050 Khordha, Odisha, India
}

Received 31 October 2020; accepted 13 January 2021

\author{
Highlights \\ Uncontrolled dumping of coal mine spoil impaired the forest soil physico-chemical properties. \\ $>$ Presence of seasonal variation in SQI. \\ The top soil at depth $0-10 \mathrm{~cm}$ and autumn season have the highest SQI. \\ Screening of Nagaland region tropical forest soil.
}

\begin{abstract}
The present study was conducted at a coal mining affected forest and a non-affected forest to analyze the seasonal changes in soil physico-chemical properties, incorporate additive and weighted soil quality index (SQI) to determine the soil quality and check the affected forest soil pollution status. Comparative SQI shows that the non-affected forest presented higher SQI in all the seasons (winter, spring, summer and autumn). However, in both the forest the seasonal additive and weighted SQI was categorised as autumn > summer > spring > winter and the overall SQI of the soil depth was ranked as $0-10>10-20>20-30 \mathrm{~cm}$. The Single pollution index (PI) points out that cadmium (Cd) was the main potential contributor to soil pollution while the Pollution load index (PLI) and Nemerow integrated pollution index (NIPI) revealed moderate soil pollution status. The result summarized that coal mining activities can elevate soil deterioration rate, such as loss in soil organic carbon, reduction in nutrient availability, and slowing down the rejuvenating process of forest soil.
\end{abstract}

Keywords: Changki forest, coal mines, pollution indices, soil quality indicators, weighted and additive SQI.

\section{Introduction}

The forest cover in India is about $24 \%$ of the total geographical area and varies from tropical evergreen forests (Andaman and Nicobar Islands, Western Ghats and Northeastern states) to dry alpine scrub in the high Himalayan region (Mishra et al., 2019). Over the years of anthropogenic activities such as indiscriminate timber and fuel wood extraction, clear-felling for shifting cultivation and mining excavation (Adetunji et al., 2005) have altered the forest landscape across the country. Northeast India, a mega biodiversity hotspot region, has been facing a tremendous challenge on forest soil quality due to illegal coal mining practices particularly in the tribal dominant state of Meghalaya and Nagaland. The removal of forest cover has greatly affected the soil characteristics, including soil fertility, chemistry, and texture (Lindenmayer \& Burgman,
2005) of the region. Coal mining also leads to the extensive loss of natural Carbon sink and further emission of $\mathrm{CO}_{2}$ in atmosphere (Ahirwal et al., 2017; Ahirwal \& Maiti, 2017). Underground and open-pit coal mining includes a phase of development that involves the removal of native soils and surrounding rocks, which are low in coal content $(<30 \%)$, high in iron sulfide minerals and toxic metals. Variety of rock types with different compositions are exposed to atmospheric conditions and undergo accelerated weathering and these materials are often deposited nearby as mine waste dumps (Bhuiyana et al., 2010). These mine dumps leads to declination of the soil quality due to stock piling of overburden (OB) dumps (Mukhopadhyay \& Maiti, 2011), as these dumps are low in Soil Organic Carbon (Ahirwal et al., 2017), poor in nutrients, contain loosely adhered particles of shale, stones, boulders, cobbles, and so forth devoid of real soil characters (Mukhopadhyay et al.,

${ }^{*}$ Corresponding author. E-mail: khikeyasemy@gmail.com 
2014; Boruah, 2006). The excavation and dumping of the overburden dumps from coal mines when deposited in forest areas become mine spoils, which ultimately change the landscape of the area and create various environmental issues (Mukhopadhyay et al., 2013; Maiti, 2007). Coal mining industry being the largest contributor $(\sim 70 \%)$ of total power generation in India, it leads to severe land degradation of forest areas (Maiti, 2013). Therefore, forest soil ecology is greatly influenced by such external pressures which can modify the standing forest structure and deteriorate environmental quality. Mukhopadhyay and Maiti (2011) and Ahirwal and Maiti (2018) have demonstrated that reclaimation and revegetation can be adopted in mining affected forest areas. Thus, it is important to check the current forest soil status and establish appropriate soil quality indicators from the physical, chemical and biological soil variables that are sensitive enough to describe the effect of different impacts on the soil (Moffat, 2003). To avoid difficulty in interpreting the complex nature of soil characteristics, a numerical dimensionless Soil Quality Index (SQI), focused on the integration of considered soil properties is calculated to evaluate soil quality (Mukhopadhyay et al., 2016). With the increase of land-use pressures, assessment on soil quality is in rising demand, thus a standard set of protocols and procedures to assign a SQI would be beneficial (Armenise et al., 2013) especially in India where overpopulation has resulted in excessive land-use practices even in the forested regions. Over the years integrating soil quality by means of indices has been successfully adopted both at a regional scale and on-farm level (Glover et al., 2000; Masto et al., 2008) through the use of weighted SQI and additive SQI. Although SQI has been extensively used as a tool to evaluate crop productivity (Liu et al., 2014), agro soil fertility (Estrada-Herrera et al., 2017) and agroecosystem (Triantafyllidis et al., 2018) there is a perceptible lack of studies using SQI to monitor seasonal soil quality on forest soils affected by coal mining activities, though it is often regarded as the most environmentally degrading activity in developing countries. This lack of knowledge is especially evident for India, where most soil quality studies have concentrated on agricultural and horticultural sectors (Bhardwaj et al., 2011). In India, heavy metal pollution due to coal mining has been reported by Ladwani et al. (2012), Manna and Maiti (2018) and Raj et al. (2019). So far only a few studies from the northeastern part of India, mainly confined to Assam (Tapadar \& Jha, 2015; Talukdar et al., 2016) and Meghalaya (Marbaninang et al., 2014), have been reported. Thus, the need arises to undertake research in the aforementioned subject. By selecting a forest disturbed by coal mining activities and an undisturbed community forest, an attempt was made to study the following objectives: to examine the seasonal variations in the soil physico-chemical parameters, to comparatively determine seasonal SQI and check the coal mining affected forest soil pollution status using pollution indices.

\section{Materials and methods}

\subsection{Study area}

Nagaland lies in the northeastern Indo-Burma biodiversity hotspot of India and covers a geographical area of $16,579 \mathrm{~km}^{2}$, extending from $25^{\circ} 6^{\prime} \mathrm{N}$ to $27^{\circ} 4^{\prime} \mathrm{N}$ Latitude and $93^{\circ} 20^{\prime} \mathrm{E}$ to $95^{\circ} 15^{\prime} \mathrm{E}$ Longitude. It is bounded by the neighboring state of Arunachal Pradesh and Myanmar in the east, Manipur in the south and Assam in the northwest. The state has a subtropical to warm temperate monsoonal climate and the annual rainfall varies from 100 to $300 \mathrm{~cm}$. Monsoon seasons start from May till the end of September with June, July and August experiencing the highest rainfall. The present study was carried out in a tropical semi-deciduous forest at Changki, Mokokchung district. The non-affected forest (NAF) is geographically located at $26^{\circ} 24^{\prime} 40^{\prime \prime} \mathrm{N} 94^{\circ} 23^{\prime} 31^{\prime \prime} \mathrm{E}$ at an altitude of $598 \mathrm{~m}$ while the coal mining-affected forest (CMAF) is located $45 \mathrm{~m}$ away from the Merayim coal fields and lies at $26^{\circ} 26^{\prime} 18^{\prime \prime} \mathrm{N} 94^{\circ} 22^{\prime} 48^{\prime \prime} \mathrm{E}$ at an altitude of $248 \mathrm{~m}$. Merayim coal fields cover an area of 52,000 $\mathrm{m}^{2}$ and annually on average, 250 tons of overburden mine spoils (Figure 1) are dumped at the CMAF, which has drastically reduced the vegetation cover and changed the forest landscape. The dominant tree species in the CMAF are Quercus serrata, Gnetum gnemon and Croton persimilis while invasive species like Lantana camara, Chromolaena odorata and Thysanolaena maxima were distributed in contiguous and clump dispersion pattern in the forest. The CMAF dumping sites have an increased growth of weeds such as Eleusine indica, Mimosa pudica and Eupatorium adenophorum.

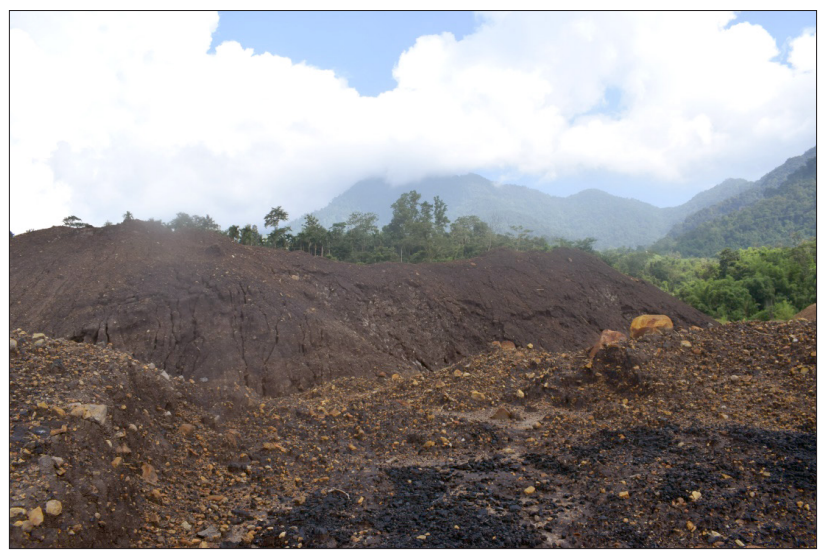

Figure 1. The overburden dumps at the coal mining affected forest floor

\subsection{Soil sampling and analysis}

Soil samples were collected from CMAF and NAF in the second week of every month from September 2018 to August 2019. Later, the monthly data were categorized into four seasonal mean values, Viz., winter (November, December and January), spring (February, March and April), summer (May, June and July), and autumn (August, September and October) based on the climatic conditions of 
Nagaland. Soils were sampled using a sampling corer (area of $\left.10 \mathrm{~cm}^{2}\right)$ from three layers depth $(0-10 \mathrm{~cm}, 10-20 \mathrm{~cm}$, and $20-30 \mathrm{~cm}$ ), collected in airtight polythene bags, and were taken to the laboratory. Unwanted debris, forest litters, stones, and gravels were removed from the samples; after that, it was air-dried at room temperature and grounded into fine particles that could pass through a 2-mm nylon sieve. Apart from soil moisture and bulk density, the other parameters were analyzed using air-dried soil samples. Parameters such as $\mathrm{pH}$ and electrical conductivity (EC) were measured by digital $\mathrm{pH}$ and electrical conductivity meter (1:5 w/v, distilled water), soil moisture using the gravimetric method (Misra, 1968), clay content by pipette method proposed by Piper (1942), bulk density (BD) using core method (Allen, 1989), organic carbon (OC) was determined using $\mathrm{K}_{2} \mathrm{Cr}_{2} \mathrm{O}_{7}$ wet oxidation method (Walkley \& Armstrong Black, 1934), available nitrogen $\left(\mathrm{N}_{\mathrm{av}}\right)$ by the $\mathrm{KMnO}_{4}$ oxidation method following Kjeldahl (1883) (Kelplus nitrogen estimation system), Available phosphorus $\left(\mathrm{P}_{\mathrm{av}}\right)$ following Bray's no. 1 extract method (Bray \& Kurtz, 1945) using UV-Vis spectrophotometer, Exchangeable potassium $\left(\mathrm{K}_{\mathrm{ex}}\right)$ using flame photometer (Photometric method) following Trivedy and Goel (1986), and cation exchange capacity (CEC) was determined following Bower et al. (1952). For heavy metals analysis, the CMAF soil samples from the four seasons were aggregated as one and digested following the Nitric-hydrochloric acid digestion method (Ang \& Lee, 2005) for the detection of five heavy metals Viz., Zinc (Zn), Cadmium (Cd), Copper $(\mathrm{Cu})$, Nickel $(\mathrm{Ni})$, and Lead $(\mathrm{Pb})$ which were determined quantitatively using Perkin Elmer, Atomic Absorption Spectrometer (AAS) AAnalyst - 700. Triplicate readings were taken for all the assays and the arithmetic means were used for the present study.

a)

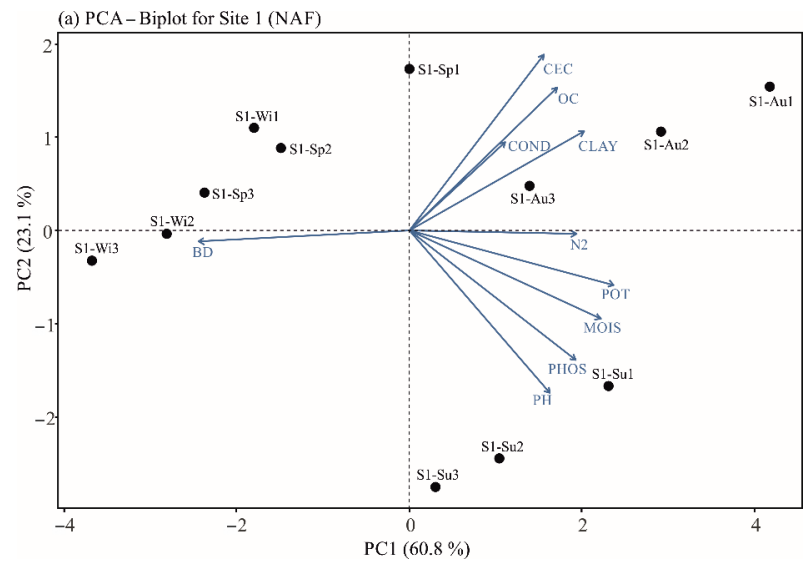

\subsection{Statistical analysis}

Seasonal mean values ( \pm standard deviation) were calculated from the three soil depth to test the significant differences among the four seasons at each site by analysis of variance (one-way ANOVA) followed by Tukey-Post hoc test $(p<0.05)$, which were performed using the statistical software SPSS (Build 1.0.0.1447).

\subsection{Soil quality index (SQI) evaluation}

SQI value was calculated using additive and weighted methods following Andrews et al. (2003) and Marzaioli et al. (2010). Three main steps were involved in finding the SQI, which required: the selection of a minimum data set (MDS) of parameter among the measured parameters that could best represent the soil function; followed by scores assigned to the MDS parameters according to their performance of soil function; and finally integrating these scores to determine the index of soil quality. MDS was determined using PCA, which was run on the normalized data matrix using the inbuilt $\mathrm{R}$ function "princomp" in Rstudio (RStudio Team, 2020). PCA results was visualized using biplots representing dominant principal components, individual samples and variables (Figure 2a and 2b). It was plotted using "fviz_pca_biplot" function of "factoextra package" (Kassambara \& Mundt, 2020). The principal components having a very high eigenvalue $(>1)$ along with the variables having higher factor loading (Varimax rotated) are assumed to be variables that can better represent the attribute of the system. Here, only those principal components with eigenvalues greater than 1 (Mandal et al., 2008) were selected and along with the criterion that it should explain a minimum of $5 \%$ of the variation in the data (Nabiollahi et al., 2017). For each principal component considered, variables having very

b)

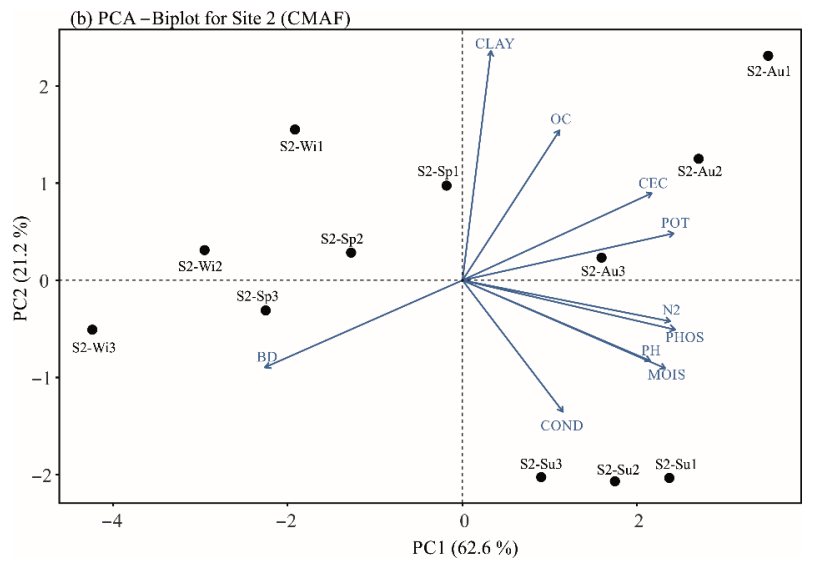

Note: ${ }^{\star} \mathrm{S} 1$ - Non-affected forest, S2 - Coal mining affected forest, Wi1 - winter $(0-10 \mathrm{~cm})$, Wi2 - winter $(10-20 \mathrm{~cm})$, Wi3 - winter $(20-30 \mathrm{~cm})$, Sp1 - spring $(0-10 \mathrm{~cm})$, Sp2 - spring $(10-20 \mathrm{~cm})$, Sp3 - spring $(20-30 \mathrm{~cm})$, Su1 - summer $(0-10 \mathrm{~cm})$, Su2 - summer $(10-20 \mathrm{~cm})$, Su3 - summer $(20-30 \mathrm{~cm})$, Au1 - autumn $(0-10 \mathrm{~cm})$, Au2 - autumn $(10-20 \mathrm{~cm})$, Au3 - autumn $(20-30 \mathrm{~cm})$.

${ }^{\star} \mathrm{BD}$ - bulk density, $\mathrm{OC}$ - soil organic carbon, CEC - cation exchange capacity, POT - exchangeable potassium, N2 - available nitrogen, PHOS - available phosphorus, MOIS - moisture, COND - electrical conductivity

Figure 2. a) Principal component analysis (PCA) based on soil physico-chemical parameters and the seasonal soil depth in NAF, b) PCA based on soil physico-chemical parameters and the seasonal soil depth in CMAF 
high factor loading with absolute values within $10 \%$ of the highest factor loading are regarded as highly weighted factors and thus were retained for MDS. To reduce the redundancy among the highly weighted variables, given that more than one factor are present for a single principal component, Pearson's correlation coefficients among the highly weighted variables are required to determine those redundant variables and to be eliminated from the MDS (Andrews et al., 2002; Guo et al., 2018; Yu et al., 2018). The variable with the highest factor loading was selected for the MDS, whereas all the other highly correlated variables were recognized to be redundant, and thus only one variable was considered for the MDS.

The SQI (Additive and Weighted) values were calculated for each observation using the following equations:

$$
\begin{aligned}
& \text { SQI }(\text { Additive })=\sum_{i=1}^{n} S i / n ; \\
& \text { SQI }(\text { Weighted })=\sum_{i=1}^{n} W i S i,
\end{aligned}
$$

where: $n$ is the number of parameters included in MDS, $\mathrm{Si}$ is the score for the variable in the MDS, and $\mathrm{W} i$ is the weighing factor derived from the PCA results.

A linear scoring method (Andrews et al., 2002) was followed to calculate the values of $S$ for each observation in the MDS. The parameters were qualitatively grouped into "good" or "bad." A "good" parameter was considered to improve the soil quality; whereas, a "bad" parameter was considered to deteriorate the soil quality. Parameters identified as good for the soil are placed as "more is better". Observation having the highest observed value is assigned to have a score of 1 . For all the corresponding observations, the $S$ values are calculated as the ratio of the observed value over the highest observation value. Similarly, parameters identified as bad for the soil are tagged as "less is better"; the lowest loaded value was assigned a score of 1 , and the $S$ values for all the corresponding observations were calculated as the ratio of the lowest value over the observed value of samples for each variable (Guo et al., 2018). The methods discussed in Sharma et al. (2005) were used to calculate the values of $W$ using the PCA results.

\subsection{Calculation of pollution indices}

The heavy metal concentration in soil extracts were calculated on the basis of dry weight $\left(\mathrm{mg} \mathrm{kg}^{-1}\right)$ and the indices of soil pollution were determined by the following methods:

\subsubsection{Single pollution index (PI)}

PI determines a specific heavy metal representing the highest threat for a soil environment. The PI equation, as defined by Lacutusu (2000), was used for the derivation of the contamination factors.

$$
\mathrm{PI}=\frac{\mathrm{Cn}}{\mathrm{GB}} \text {, }
$$

where: $\mathrm{Cn}$ is the content of heavy metal in CMAF soil, and GB is the values of the geochemical background (Table 1).

Table 1. Heavy metal concentration of coal mining-affected forest (CMAF) soil and Geochemical background (GB)

\begin{tabular}{|c|c|c|}
\hline Elements & CMAF Soil $\left(\mathrm{mg} \mathrm{kg}^{-1}\right)$ & ${ }^{\star} \mathrm{GB}$ average $\left(\mathrm{mg} \mathrm{kg}^{-1}\right)$ \\
\hline $\mathrm{Zn}$ & $54 \pm 0.89$ & 70 \\
\hline $\mathrm{Cd}$ & $2.4 \pm 0.076$ & 0.41 \\
\hline $\mathrm{Cu}$ & $35.4 \pm 0.95$ & 38.9 \\
\hline $\mathrm{Ni}$ & $18 \pm 0.78$ & 29 \\
\hline $\mathrm{Pb}$ & 0 & 27 \\
\hline
\end{tabular}

Note: ${ }^{\star} \mathrm{GB}$ value of heavy metals in surface soils over the world (average, $\mathrm{mg} \mathrm{kg}^{-1}$ ) (Kabata-Pendias, 2010).

\subsubsection{Pollution load index (PLI)}

The total assessment of the degree of contamination in soil is estimated using PLI. It is calculated as a geometric average of PI based on the following formula given by Thomilson et al. (1980).

$$
\mathrm{PLI}=\left[\mathrm{PI}_{1} \times \mathrm{PI}_{2} \times \mathrm{PI}_{3} \times \ldots \times \mathrm{PI}_{n}\right]^{1 / n},
$$

where: $n$ is the number of analyzed heavy metals, and PI is the calculated values for the single pollution index.

\subsubsection{Nemerow integrated pollution index (NIPI)}

The NIPI assesses the overall pollution integrity of the area and is calculated as formulated by Nemerow (1985).

$$
\mathrm{NIPI}=\left[0.5 \times\left(I_{\text {mean }}^{2}+I_{\max }^{2}\right)\right]^{1 / 2},
$$

where: $I_{\text {mean }}$ is the average concentration of all pollution indices considered, and $I_{\max }$ is the maximum pollution index.

Soil pollution models and their classification schemes utilized in the study are shown in Table 2.

\section{Results and discussion}

\subsection{Seasonal soil variables}

The soil $\mathrm{pH}$ in NAF and CMAF shows a mean statistical difference at $p<0.05$ between the seasons as shown in Table 3. The post hoc test for BD in CMAF reveals winter-autumn $(p=0.024)$ and spring-autumn $(p=0.038)$ as statistically different while in NAF a statistical significant difference was recorded between winter-summer $(p=.003)$, winter-autumn $(p<.001)$ and spring-autumn $(p=.004)$. In both the forests' maximum mean soil moisture was observed in summer and a significant difference $(P<0.001)$ was recorded among the seasons. Clay percentage in CMAF was recorded highest in autumn and lowest in winter, however, there was no significant difference among the seasons $(F=3.662 ; P=0.063)$. In NAF the clay content, EC and CEC show no significant difference between the seasons. Mean values of EC in the disturbed forest was recorded highest in summer, with a significant 
Table 2. Soil pollution status models and the classification schemes utilized in the study

\begin{tabular}{|c|l|c|l|c|l|}
\hline \multicolumn{2}{|c|}{$\begin{array}{c}\text { Single Pollution Index/Contamination } \\
\text { Index }\end{array}$} & \multicolumn{2}{|c|}{ Pollution Load Index } & \multicolumn{2}{c|}{$\begin{array}{c}\text { Nemerow Integrated Pollution } \\
\text { Index }\end{array}$} \\
\hline$<0.1$ & Very slight contamination & $>0$ PLI $\leq 1$ & Unpolluted to moderately polluted & $\leq 0.7$ & Safe \\
\hline $0.1-0.25$ & Slight contamination & $>1$ PLI $\leq 2$ & Moderately polluted & $>0.7$ NIPI $\leq 1$ & Precaution \\
\hline $0.26-0.5$ & Moderate contamination & $>2$ PLI $\leq 3$ & Moderately to highly polluted & $>1$ NIP $\leq 2$ & Slightly polluted \\
\hline $0.51-0.75$ & Severe contamination & $>3$ PLI $\leq 4$ & Highly polluted & $>2$ NIP $\leq 3$ & Moderately polluted \\
\hline $0.76-1.0$ & Very severe contamination & $\geq 5$ & Very highly polluted & $>3$ & Heavily polluted \\
\hline $1.1-2.0$ & Slight pollution & - & - & - & - \\
\hline $2.1-4.0$ & Moderate pollution & - & - & - & - \\
\hline $4.1-8.0$ & Severe pollution & - & - & - & - \\
\hline $8.1-16$ & Very severe pollution & - & - & - & - \\
\hline$>16$ & Excessive pollution & - & - & - \\
\hline
\end{tabular}

difference $(F=84.818 ; p<0.001)$ between the seasons. The CMAF soil parameter CEC was significantly different for winter-spring $(p=0.005)$, winter-summer $(p=0.004)$, winter-autumn $(p<0.001)$, spring-autumn $(p<0.001)$ and summer-autumn $(p<0.001)$. Soil organic carbon was low $(\mathrm{OC}<2.0 \%)$ in the CMAF soil (Feiza et al., 2011) and did not show any significant seasonal difference at $p<0.05$ level. While seasonal SOC in NAF was recorded maximum in autumn and differed significantly with winter $(p<.001)$, spring $(p=.001)$ and summer $(p<.001) . \mathrm{P}_{\mathrm{av}}$ in CMAF shows a statistical difference for winter-summerautumn $(p=0.001)$ and spring-summer $(p=0.012)$ while in NAF a significant difference $(p<.001)$ was observed among the seasons. In the disturbed forest, the $\mathrm{K}_{\mathrm{ex}}$ was significantly different $(p=0.017)$ for only two seasons (winter-autumn). Mean $\mathrm{K}_{\mathrm{ex}}$ in NAF was highest in autumn and lowest in winter with a statistically significant difference $(p=.001)$ between the seasons. Analysis of variance for $\mathrm{N}_{\mathrm{av}}$ in CMAF at $p<0.05$ mean difference level was tenable between winter-summer $(p=.0008)$, winter-autumn $(p=.020)$, spring-summer $(p=.016)$ and spring-autumn $(p=0.043)$. In NAF maximum mean $\mathrm{N}_{\mathrm{av}}$ was recorded in autumn and minimum in spring while a seasonal significant difference was recorded at $p<0.05$ level. The acidic nature of the soil in coal mining affected forest is widely reported (Rai et al., 2011) as coal spoils are rich in pyrites, sulfates and toxic metals their oxidation can acidify the forest soil $\mathrm{pH}$. Specifically, the seasonal CMAF soil has medium to high BD $\left(1.32-1.57 \mathrm{~g} \mathrm{~cm}^{-3}\right)$ (Brzezinska et al., 2011), with little capacity for moisture retention due to compaction of forest soil caused by human and machinery activities. The surface soil (0-10 cm depth) has maximum nutrient concentration and decreases with depth in all the seasons at both the forest (Table 4). A similar trend was reported by Mishra et al. (2019) on Nagaland tropical forest soil. In accordance with Department of Agriculture and Cooperation Ministry of Agriculture [DACMA], Govt. of India (2011) standards, the CMAF soil has very low $\mathrm{N}_{\mathrm{av}}$, $\mathrm{P}_{\mathrm{av}}$ and medium range of $\mathrm{K}_{\mathrm{ex}}$. Comparative soil parameters also indicate higher amount of CEC, $\mathrm{N}_{\mathrm{av}}, \mathrm{P}_{\mathrm{av}}, \mathrm{SOC}$, soil moisture, clay and $\mathrm{K}_{\mathrm{ex}}$ in NAF. The finding shows that
NAF soil quality is supported by thick vegetation cover which provides essential organic matter in supporting the rejuvenating process of the soil and its nutrient concentration. Seasonal climatic variation may have influenced the changes in soil properties through its aggregate effects in both the forest. Nonetheless, in CMAF, the area is influenced by mining practices, deforestation, logging, soil erosion and overburden dumps from coal mines, which ultimately has its impact on the soil properties. The overall soil profile presented that the deteriorated soil quality in CMAF is marked with relatively low $\mathrm{pH}$, low nutrients content, and limited soil organic carbon which is consistent with previous reports on coal mining affected forest soil (Sarma, 2002; Rai et al., 2011).

Table 3. One-way Anova (analysis of variance) with $\mathrm{P}$ and $\mathrm{F}$ value between groups of seasonal soil parameters at the nonaffected and coal mining affected forest

\begin{tabular}{|c|c|c|c|c|}
\hline \multirow{2}{*}{ Parameters } & \multicolumn{2}{|c|}{ NAF } & \multicolumn{2}{c|}{ CMAF } \\
\cline { 2 - 5 } & $P$-value & $F$-value & $P$-value & $F$-value \\
\hline $\mathrm{pH}$ & $<.001$ & 50.96 & $<.001$ & 65.48 \\
\hline Moisture & $<.001$ & 19.41 & $<.001$ & 67.51 \\
\hline Clay & .223 & 1.81 & .064 & 3.63 \\
\hline $\mathrm{BD}$ & $<.001$ & 23.72 & .022 & 5.73 \\
\hline $\mathrm{EC}$ & .006 & 8.99 & $<.001$ & 85.17 \\
\hline $\mathrm{CEC}$ & .007 & 8.59 & $<.001$ & 54.77 \\
\hline $\mathrm{SOC}$ & $<.001$ & 33.02 & .219 & 1.835 \\
\hline $\mathrm{P}_{\mathrm{av}}$ & $<.001$ & 45.48 & $<.001$ & 21.6 \\
\hline $\mathrm{K}_{\mathrm{ex}}$ & $<.001$ & 16.07 & .016 & 6.37 \\
\hline $\mathrm{N}_{\mathrm{av}}$ & $<.001$ & 27.11 & .003 & 10.87 \\
\hline
\end{tabular}

\subsection{Seasonal soil quality}

PCA of statistically significant variables are presented in Table 5. The normalized varimax rotation of PCA corresponding to NAF and CMAF explained $95 \%$ and $84 \%$ of the total data variance. In NAF, $\mathrm{P}_{\mathrm{av}}$ of PC1, CEC of PC2 and EC of PC3 were selected for the MDS while in CMAF, 


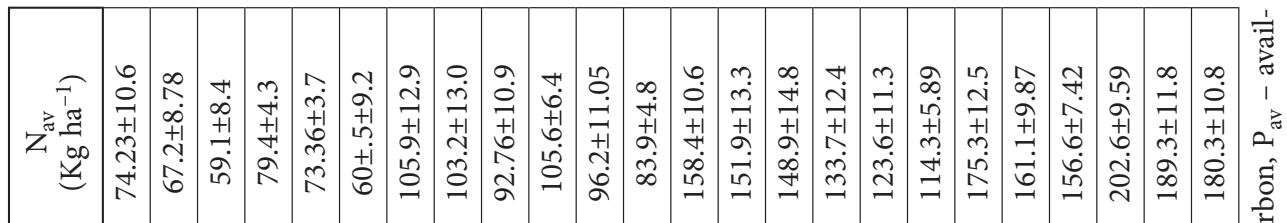

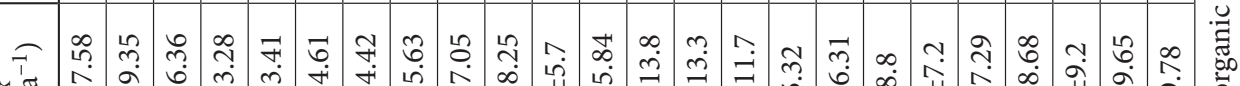

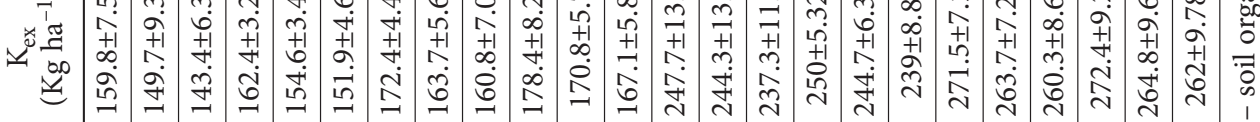

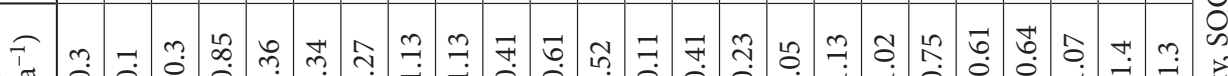

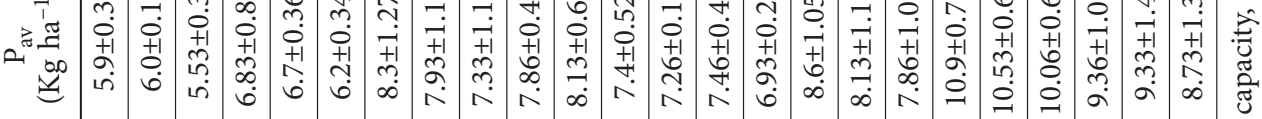

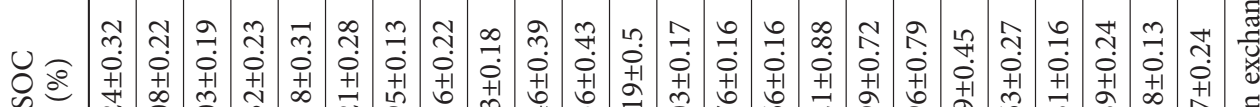

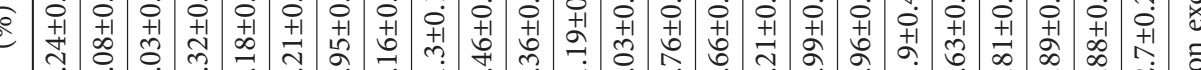

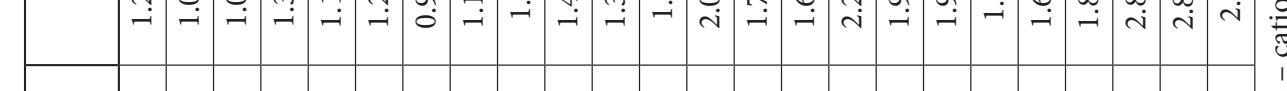

כ)

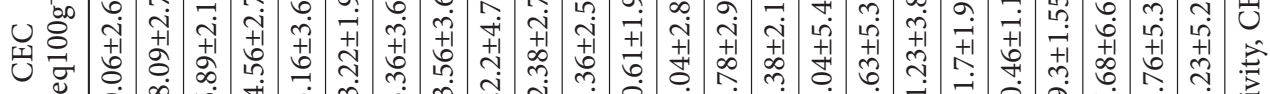

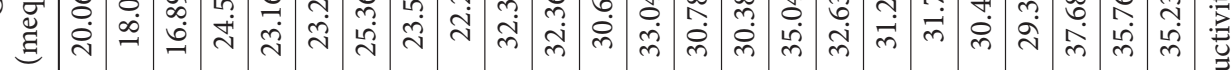

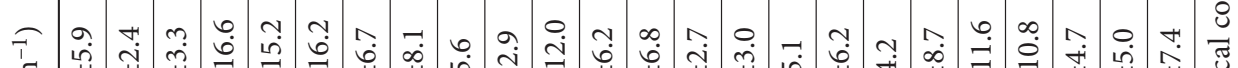

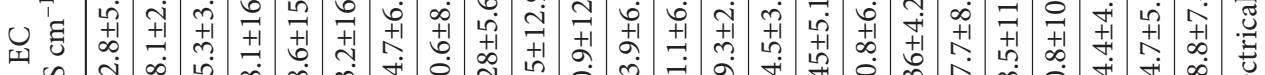

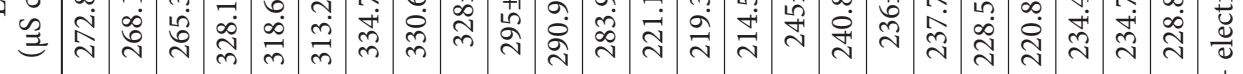

望

T

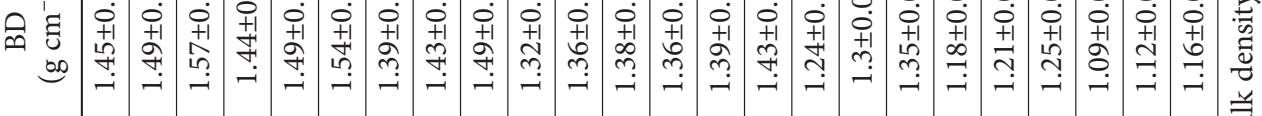

苋

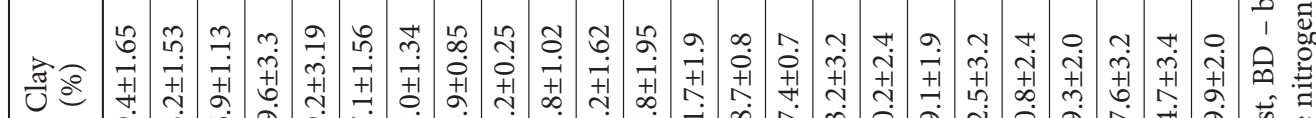

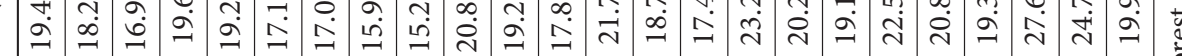

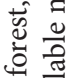

莺 .

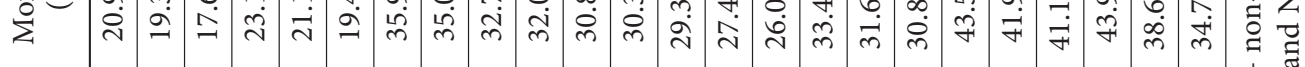

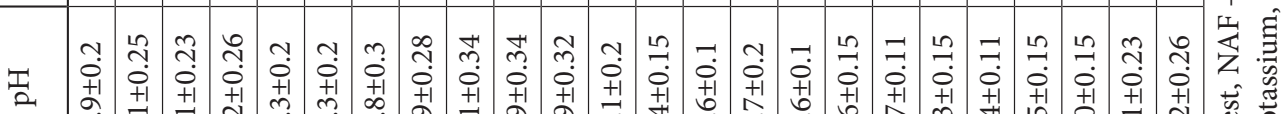

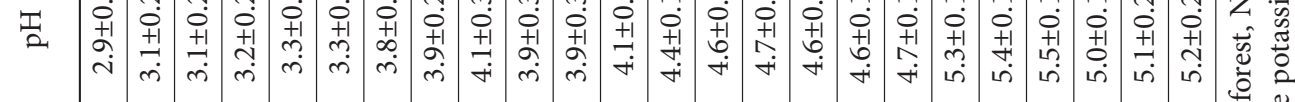

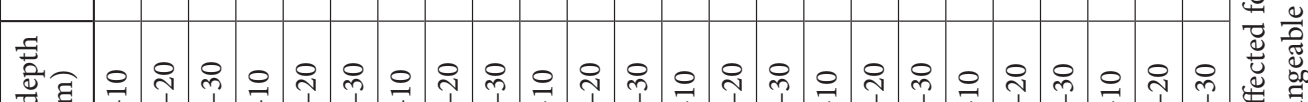

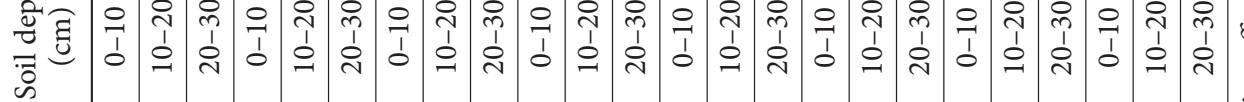

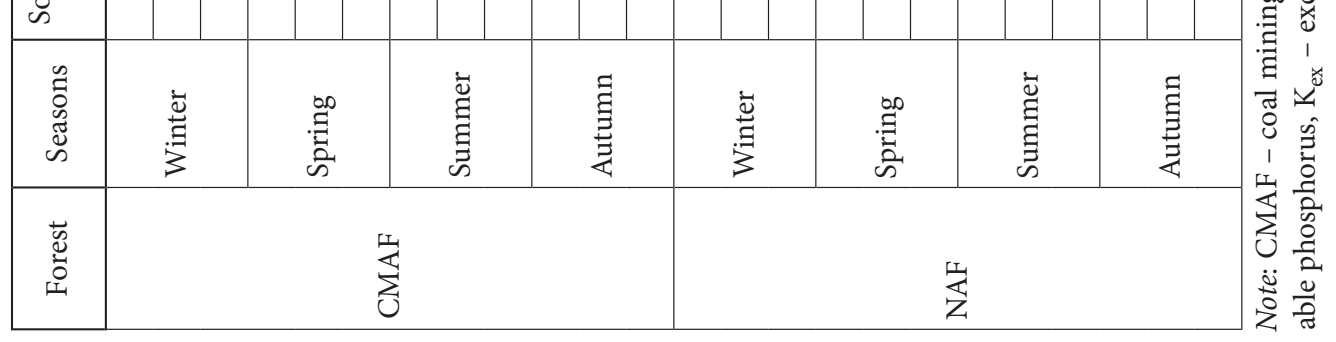


soil moisture of PC1 and clay of PC2 were retained in the MDS. Hence, considering their properties, $\mathrm{P}_{\mathrm{aw}}$, $\mathrm{CEC}$, soil moisture and clay were tagged as good parameters and EC as a bad parameter/optimum for soil quality. After scoring and weights assigned to the indicators, the seasonal SQI was calculated using the integrated quality index Equations (1) and (2). The overall SQI value decreases from $0-10 \mathrm{~cm}$ to $20-30 \mathrm{~cm}$ of soil depth in both equations (Figure $3 \mathrm{a}$ and $3 \mathrm{~b}$ ). A similar trend of the result was reported by Vasu et al. (2016) on their study of additive SQI in a semi-arid Deccan plateau. Table 6 presents the overall seasonal SQI mean value from the three layers of soil depth. The NAF and CMAF seasonal SQI are categorized as autumn $>$ summer $>$ spring $>$ winter for additive and weighted SQI. However, comparative seasonal soil quality status shows that NAF has a greater SQI value than CMAF. The SQI values presented by Liu et al. (2014) on clayey paddy soils were recorded maximum in high productivity paddy soil $(0.82)$ and minimum in low productivity paddy soil $(0.50)$. Their results reflected that the better the soil quality, the higher is the SQI. Thus, in the NAF and CMAF, autumn season can be tagged with the "highest soil productivity" and the soil depth $0-10 \mathrm{~cm}$ in all the seasons as the "most productive" soil layer.

Table 5. Principle component analysis result of significant soil quality indicators considered for minimum data set

\begin{tabular}{|l|c|c|c|c|c|}
\hline \multicolumn{1}{|c|}{ Forest } & \multicolumn{3}{c|}{ NAF } & \multicolumn{2}{c|}{ CMAF } \\
\hline Principal component & PC-1 & PC-2 & PC-3 & PC-1 & PC-2 \\
\hline Eigen value & 6.08 & 2.31 & 1.16 & 6.25 & 2.11 \\
\hline \% Variance & 44 & 38 & 13 & 55 & 29 \\
\hline $\begin{array}{l}\text { \% Cumulative } \\
\text { variance }\end{array}$ & 44 & 82 & 95 & 55 & 84 \\
\hline Factor loadings & & & & & \\
\hline CEC & -0.03 & 0.97 & 0.22 & 0.62 & 0.69 \\
\hline $\mathrm{N}_{\text {av }}$ & 0.55 & 0.67 & -0.46 & 0.92 & 0.26 \\
\hline SOC & 0.1 & 0.94 & 0.07 & 0.13 & 0.74 \\
\hline pH & 0.95 & -0.05 & -0.16 & 0.91 & 0.07 \\
\hline Soil Moisture & 0.94 & 0.26 & 0.16 & 0.98 & 0.07 \\
\hline Clay & 0.34 & 0.81 & 0.28 & -0.28 & 0.9 \\
\hline EC & 0.15 & 0.32 & 0.93 & 0.64 & -0.29 \\
\hline Bulk Density & -0.71 & -0.65 & -0.21 & -0.65 & -0.7 \\
\hline $\mathrm{K}_{\text {ex }}$ & 0.87 & 0.48 & -0.01 & 0.78 & 0.59 \\
\hline $\mathrm{P}_{\text {av }}$ & 0.97 & 0.02 & 0.22 & 0.96 & 0.24 \\
\hline
\end{tabular}

Note: ${ }^{\star} \mathrm{PC}$ - principal components; Factor loadings are Varimax rotated, and italicized factor loadings are considered highly weighted; Bold italicized factors are identified indicators retained in the MDS.

\subsection{Pollution status of the soil}

The PI demonstrated that the soil status ranges from "severe contamination" to "severe pollution". The recorded value of $\mathrm{Ni}(0.62)$ falls under "severe contamination" while $\mathrm{Zn}(0.77)$ and $\mathrm{Cu}(0.91)$ are "very severely contaminated".
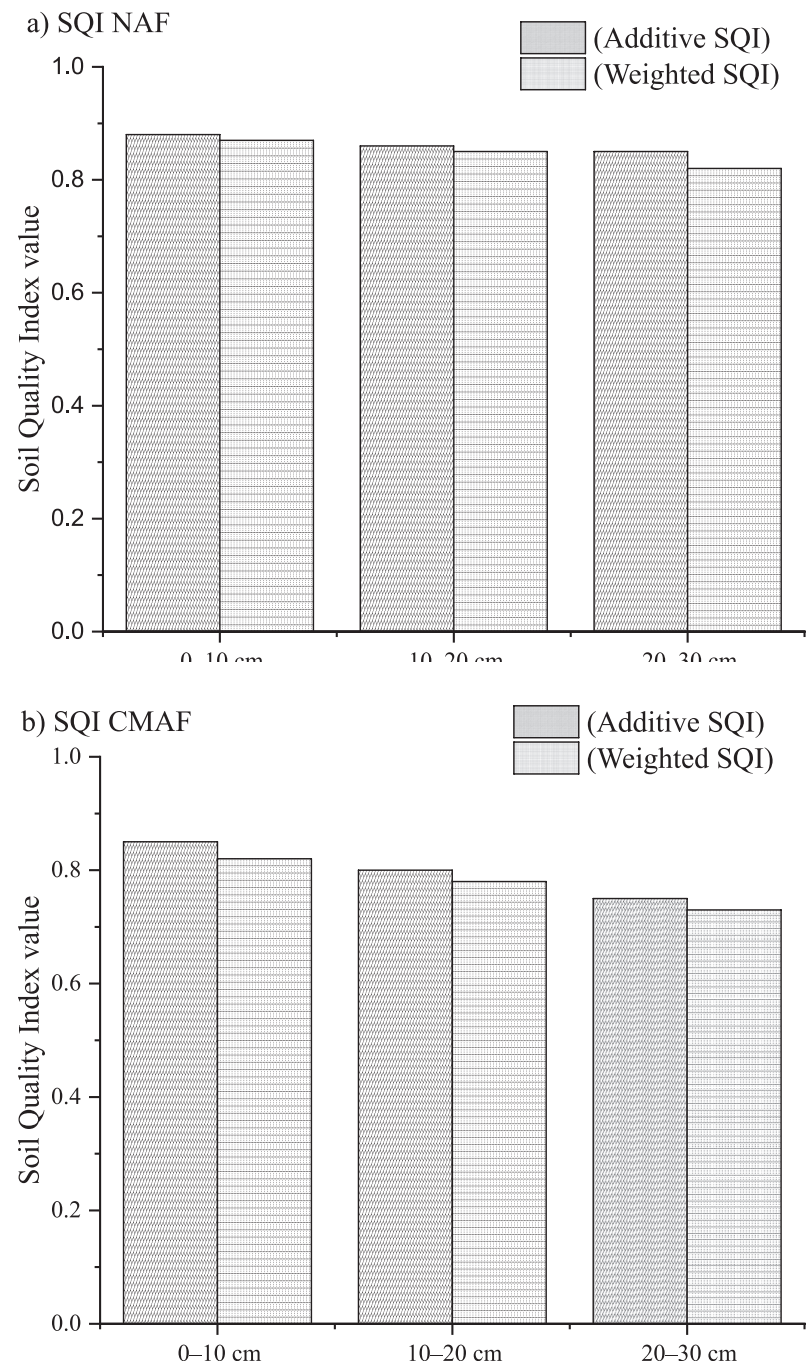

Figure 3. a) Overall soil quality index in non-affected forest soil of the three soil depths, b) Overall soil quality index in coal mining-affected forest of the three soil depths

Table 6. Overall seasonal soil quality index mean value $( \pm \mathrm{SD})$ from the three layers soil depth

\begin{tabular}{|l|c|c|c|c|}
\hline \multirow{2}{*}{ Seasons } & \multicolumn{2}{|c|}{ Additive SQI } & \multicolumn{2}{c|}{ Weighted SQI } \\
\cline { 2 - 5 } & NAF & CMAF & NAF & CMAF \\
\hline Winter & $0.83 \pm 0.01$ & $0.70 \pm 0.05$ & $0.78 \pm 0.02$ & $0.65 \pm 0.7$ \\
\hline Spring & $0.84 \pm 0.02$ & $0.74 \pm 0.05$ & $0.83 \pm 0.03$ & $0.69 \pm 0.74$ \\
\hline Summer & $0.9 \pm 0.01$ & $0.86 \pm 0.04$ & $0.89 \pm 0.02$ & $0.89 \pm 0.86$ \\
\hline Autumn & $0.91 \pm 0.01$ & $0.89 \pm 0.04$ & $0.90 \pm 0.02$ & $0.88 \pm 0.89$ \\
\hline
\end{tabular}

However, the contamination degree did not reach the "pollution level". $\mathrm{Pb}$ was not detected in the samples and only the metal Cd (5.83) shows "severe pollution" status. The PI reveals $\mathrm{Cd}$ as the primary contributor to soil pollution, which was also reported by Niu et al. (2015), and Nwankwoala and Ememu (2018) in coal mining-affected soils. However, the result contradicts Ita and Anwana (2017) and Anwana et al. (2018), where they observed concentrations of $\mathrm{Cd}$ as relatively low compared to other 
metals. PLI (1.263) and NIPI (2.926) indicate that CMAF soil is "moderately polluted". The moderate soil pollution of CMAF can be attributed due to heavy metals rich untreated drainages and deposition of coal overburden dumps into the forest (Razo et al., 2004) as an excess concentration of heavy metals can alter soil chemistry (Jung, 2001) causing soil toxicity, thus affecting the environment substantially.

\section{Conclusions}

Uncontrolled landfills and dumping of coal mine spoil into the forest area have affected the soil physico-chemical properties and increased the degree of heavy metal contamination. The parameters $\mathrm{P}_{\mathrm{av}}, \mathrm{CEC}, \mathrm{EC}$ in NAF and soil moisture, clay in CMAF were selected as sensitive indicators and played the central role in determining the SQI. The finding implies that seasonal soil physico-chemical properties should be explicitly considered to determine soil quality status in an anthropogenically disturbed forest. As SQI accommodates different soil parameters to indicate soil quality, their integration for predicting the effect of seasonal change on soil properties will strengthen the knowledge and accuracy of soil management. In view of CMAF "moderate soil pollution" status, proper management strategies and coal mine-dumping laws should be formulated and enforced by policymakers. Our approach on the forest soil could be suitable and considered as a preliminary screening in tropical forest management, mining pollution control programs and aid to biodiversity reclamation projects.

\section{Acknowledgements}

The research work is financially supported by Council of Science and Industrial Research (CSIR), Government of India, National Eligibility Test (NET) JRF-fellowship awarded to KS, File no: 09/763(0012)/2017-EMR I. The Head, Department of Botany, Nagaland University is duly acknowledged for providing necessary laboratory facilities to proceed with the experiments. NV acknowledge CSIR for providing CSIR-JRF (09/1059(0013)/2017-EMR-I).

\section{Conflicts of interest}

The authors declare that they have no conflict of interest.

\section{Authors' contributions}

The first and third authors are research scholars; the manuscript is based on the first author PhD work. The second author is the guide of the first author under whose supervision the research is carried out. The third author has contributed in analyzing the data and imparted ideas on constructing the manuscript.

\section{References}

Adetunji, A. R., Sinyanbola, W. O., Funtua, I. I., Olusunle, S. O. O., Afonja, A. A., \& Adewoye, O. O. (2005). Assessment of beneficiation routes of Tantalite ores from key locations in Nigeria. Journal of Mineral Material Characterization and Engineering, 4(2), 85-93.

https://doi.org/10.4236/jmmce.2005.42008

Ahirwal, J., \& Maiti, S. K. (2017). Assessment of carbon sequestration potential of revegetated coal mine overburden dumps: A chronosequence study from dry tropical climate. Journal of Environmental Management, 201, 369-377.

https://doi.org/10.1016/j.jenvman.2017.07.003

Ahirwal, J., \& Maiti, S. K. (2018). Development of Technosol properties and recovery of carbon stock after 16 years of revegetation on coal mine degraded lands, India. Catena, 166, 114-123. https://doi.org/10.1016/j.catena.2018.03.026

Ahirwal, J., Maiti, S. K., \& Singh, A. K. (2017). Changes in ecosystem carbon pool and soil $\mathrm{CO}_{2}$ flux following post-mine reclamation in dry tropical environment, India. Science of the Total Environment, 583, 153-162.

https://doi.org/10.1016/j.scitotenv.2017.01.043

Allen, S. E. (1989). Chemical analysis of ecological materials ( $2^{\text {nd }}$ ed.). Blackwell Scientific Publications.

Andrews, S. S., Flora, C. B., Mitchell, J. P., \& Karlen, D. L. (2003). Grower's perceptions and acceptance of soil quality indices. Geoderma, 114(3-4), 187-213. https://doi.org/10.1016/S0016-7061(03)00041-7

Andrews, S. S., Karlen, D. L., \& Mitchell, J. P. (2002). A comparison of soil quality indexing methods for vegetable production systems in Northern California. Agriculture, Ecosystems and Environment, 90(1), 25-45.

https://doi.org/10.1016/S0167-8809(01)00174-8

Ang, H. H., \& Lee, K. L. (2005). Analysis of mercury in Malaysian herbal preparations: A peer review. Journal of Biomedical Sciences, 4(1), 31-36. http://www.bioline.org.br/pdf?jm05004

Anwana, E. D., Ita, R. E., \& Mbong, E. O. (2018). Spatial concentrations of heavy metals in soils and plants of a landfill site in Uyo, Akwa Ibom state. Cancer Biology, 8(1), 144-149. https://doi.org/10.7537/marscbj080118.09

Armenise, E., Redmile-Gordon, A. M., Stellacci, A., Ciccarese, A., \& Rubino, C. P (2013). Developing a soil quality index to compare soil fitness for agricultural use under different managements in the Mediterranean environment. Soil \& Tillage Research, 130, 91-98.

https://doi.org/10.1016/j.still.2013.02.013

Bhardwaj, A. K., Jasrotia, P., Hamilton, S. K., \& Robertson, G. P. (2011). Ecological management of intensively cropped agroecosystems improves soil quality with sustained productivity. Agricultural Ecosystem and Environment, 140(3-4), 419-429. https://doi.org/10.1016/j.agee.2011.01.005

Bhuiyan, M. A. H., Parvez, L., Islam, M. A., Dampare, S. B., \& Suzuki, S. (2010). Heavy metal pollution of coal mine-affected agricultural soils in the northern part of Bangladesh. Journal of Hazardous Materials, 173(1-3), 384-392.

https://doi.org/10.1016/j.jhazmat.2009.08.085

Boruah, D. H. P. (2006). North eastern coal and environment: An overview. In Proceedings on Characterization and Gainful Utilisation of North Eastern Coalfields of Coal India (CGU'06) (pp. 28-33), RRL, Jorhat.

Bower, C. A., Reitemeier, R. F., \& Fireman, M. (1952). Exchangeable cation analysis of saline and alkali soils. Soil Science, 73(4), 251-262. https://doi.org/10.1097/00010694-195204000-00001 
Bray, R. H., \& Kurtz, L. T. (1945). Determination of total, organic and available forms of phosphorus in soils. Soil Sciences, 59(1), 39-46.

https://doi.org/10.1097/00010694-194501000-00006

Brzezinska, M., Sokolowska, Z., Alekseeva, T., Alekseev, A., Hajnos, M., \& Szarlip, P. (2011). Some characteristics of organic soils irigated with municipal wastewater. Land Degradation and Development, 22(6), 586-595.

https://doi.org/10.1002/ldr.1036

Department of Agriculture and Cooperation Ministry of Agriculture, Government of India. (2011). Methods manual soil testing in India. New Delhi.

Estrada-Herrera, I. R., Hidalgo-Moreno, C., Guzmán-Plazola, R., Almaraz Suárez, J. J., Navarro-Garza, H., \& Etchevers-Barra, J. D. (2017). Soil quality indicators to evaluate soil fertility. Agrociencia, 51(8), 813-831.

Feiza, V., Feiziene, D., Kadziene, G., Lazauskas, S., Deveikyte, I., Slepetiene, A., \& Seibutis, V. (2011). Soil state in the $11^{\text {th }}$ year of three tillage systems application on a cambisol. Journal of Food, Agriculture and Environment, 9(3-4), 1088-1095.

Glover, J. D., Reganold, J. P., \& Andrews, P. K. (2000). Systematic method for rating soil quality of conventional, organic, and integrated apple orchards in Washington State. Agriculture, Ecosystems and Environment, 80(1-2), 29-45. https://doi.org/10.1016/S0167-8809(00)00131-6

Guo, X. M., Zhao, T. Q., Chang, W. K., Xiao, C. Y., \& He, Y. X. (2018). Evaluating the effect of coal mining subsidence on the agricultural soil quality using principal component analysis. Chilean Journal of Agricultural Research, 78(2), 173-182. https://doi.org/10.4067/S0718-58392018000200173

Ita, R. E., \& Anwana, E. D. (2017). Geochemical assessment of heavy metals contamination in rural and urban wetlands in Akwa Ibom State, Nigeria. New York Science Journal, 10(11), 43-51. http://www.sciencepub.net/newyork/ny101117/06_32 114nys101117_43_51.pdf

Jung, M. C. (2001). Heavy metal contamination of soils and waters in and around the Imcheon $\mathrm{Au}-\mathrm{Ag}$ mine, Korea. Applied Geochemistry, 16(11-12), 1369-1375. https://doi.org/10.1016/S0883-2927(01)00040-3

Kabata-Pendias, A. (2010). Trace elements in soils and plants ( $4^{\text {th }}$ ed.). CRC Press.

Kassambara, A., \& Mundt, F. (2020). Factoextra: Extract and visualize the results of multivariate data analyses ( $R$ package version 1.0.7). https://CRAN.R-project.org/package=factoextra

Kjeldahl, J. (1883). Neue methode zur bestimmung des stickstoffs in organischen korpern [New method for the determination of nitrogen in organic substances]. Zeitschrift für analytische Chemie, 22(1), 366-382. https://doi.org/10.1007/BF01338151

Lacutusu, R. (2000). Appraising levels of soil contamination and pollution with heavy metals. In H. J. Heinike, W. Eckselman, A. J. Thomasson, R. J. A. Jones, L. Montanarella, \& B. Buckley (Eds.), Land information systems developments for planning the sustainable use of land resources Luxembourg (Research Report No. 4, pp. 393-402). European Soil Bureau.

Ladwani, K. D., Ladwani, K. D., Manik, V. S., \& Ramteke, D. S. (2012). Assessment of heavy metal contaminated soil near coal mining area in Gujarat by toxicity characteristics leaching procedure. International Journal of Life Sciences Biotechnology and Pharma Research, 1(4), 73-80.

Lindenmayer, D., \& Burgman, M. (2005). Practical conservation biology. CSIRO Publishing.

Liu, Z., Zhou, W., Shen, J., Li, S., \& Ai, C. (2014). Soil quality assessment of yellow clayey paddy soils with different productivity. Biology and Fertility of Soils, 50(3), 537-548. https://doi.org/10.1007/s00374-013-0864-9
Maiti, S. K. (2007). Bioreclamation of coalmine overburden dumps-with special emphasis on micronutrients and heavy metals accumulation in tree species. Environmental Monitoring and Assessesment, 125, 111-122.

https://doi.org/10.1007/s10661-006-9244-3

Maiti, S. K. (2013). Ecorestoration of the coalmine degraded lands. Springer Science \& Business Media.

https://doi.org/10.1007/978-81-322-0851-8

Mandal, U. K., Warrington, D. N., Bhardwaj, A. K., Bar-Tal, A., Kautsky, L., Minz, D., \& Levy, G. J. (2008). Evaluating impact of irrigation water quality on a calcareous clay soil using principal component analysis. Geoderma, 144(1-2), 189-197. https://doi.org/10.1016/j.geoderma.2007.11.014

Manna, A., \& Maiti, R. (2018). Geochemical contamination in the mine affected soil of Raniganj Coalfield - A river basin scale assessment. Geoscience Frontiers, 9(5), 1577-1590. https://doi.org/10.1016/j.gsf.2017.10.011

Marbaninang, D., Das, P., \& Chaturvedi, S. S. (2014). Assessment of heavy metal pollution in abandoned coal stockpile and Lime Kiln of Meghalaya using Pollution Load Index (PLI) and Geoaccumulation Index (I-Geo). International Journal of Science and Research, 3(9), 886-891.

Marzaioli, R., D’Ascoli, R., De Pascale, R. A., \& Rutigliano, F. A. (2010). Soil quality in a Mediterranean area of Southern Italy as related to different land use types. Applied Soil Ecology, 44(3), 205-212. https://doi.org/10.1016/j.apsoil.2009.12.007

Masto, R. E., Chhonkar, P. K., Singh, D., \& Patra, A. K. (2008). Alternative soil quality indices for evaluating the effect of intensive cropping, fertilisation and manuring for 31 years in the semi-arid soils of India. Environmental Monitoring and Assessment, 136, 419-435. https://doi.org/10.1007/s10661-007-9697-z

Mishra, G., Marzaioli, R., Giri, K., \& Pandey, S. (2019). Soil quality assessment across different stands in tropical moist deciduous forests of Nagaland, India. Journal of Forestry Research, 30, 1479-1485. https://doi.org/10.1007/s11676-018-0720-8

Misra, R. (1968). Ecology work book. Oxford and IBH Publishing Co.

Moffat, A. J. (2003). Indicators of soil quality for UK forestry. Forestry, 76(5), 547-568. https://doi.org/10.1093/forestry/76.5.547

Mukhopadhyay, S., \& Maiti, S. K. (2011). Trace metal accumulation and natural mycorrhizal colonisation in an afforested coalmine overburden dump: A case study from India. International Journal of Mining, Reclamation and Environment, 25(2), 187-207.

https://doi.org/10.1080/17480930.2010.548663

Mukhopadhyay, S., Maiti, S. K., \& Masto, R. E. (2013). Use of Reclaimed Mine Soil Index (RMSI) for screening of tree species for reclamation of coal mine degraded land. Ecological Engineering, 57, 133-142.

https://doi.org/10.1016/j.ecoleng.2013.04.017

Mukhopadhyay, S., Maiti, S. K., \& Masto, R. E. (2014). Development of mine soil quality index (MSQI) for evaluation of reclamation success: A chronosequence study. Ecological Engineering, $71,10-20$.

https://doi.org/10.1016/j.ecoleng.2014.07.001

Mukhopadhyay, S., Masto, R., Yadav, A., Joshy, G., Lal, R., \& Shukla, S. P. (2016). Soil quality index for evaluation of reclaimed coal mine spoil. Science of the Total Environment, 542, 540-550. https://doi.org/10.1016/j.scitotenv.2015.10.035

Nabiollahi, K., Taghizadeh-Mehrjardi, R., Kerry, R., \& Moradian, S. (2017). Assessment of soil quality indices for salt-affected agricultural land in Kurdistan Province, Iran. Ecological 
Indicators, 83, 482-494.

https://doi.org/10.1016/j.ecolind.2017.08.001

Nemerow, N. L. (1985). Stream, lake, estuary, and ocean pollution. Van Nostrand Reinhold Publishing.

Niu, S., Gao, L., \& Zhao, J. (2015). Distribution and risk assessment of heavy metals in the Xinzhuangzi reclamation soil from the Huainan coal mining area, China. Human and Ecological Risk Assessment, 21(4), 900-912. https://doi.org/10.1080/10807039.2014.943572

Nwankwoala, H. O., \& Ememu, A. J. (2018). Contamination indices and heavy metal concentrations in soils in Okpoko and Environs, Southeastern Nigeria. Journal of Environmental Science and Public Health, 2(2), 77-95. https://doi.org/10.26502/jesph.96120031

Piper, C. S. (1942). Soil and plant analysis: Laboratory manual of methods for the examination of soils and the determination of the inorganic constituents of plants. Hassell Press.

Rai, A. K., Paul, B., \& Singh, G. (2011). A study on physico chemical properties of overburden dump materials from selected coal mining areas of Jharia coalfields, Jharkhand, India. International Journal of Environmental Sciences, 1(6), 1350-1360.

Raj, D., Kumar, A., \& Maiti, S. K. (2019). Evaluation of toxic metal(loid)s concentration in soils around an open-cast coal mine (Eastern India). Environment Earth Sciences, 78(22), 645. https://doi.org/10.1007/s12665-019-8657-6

Razo, I., Carrizales, L., Castro, J., Díaz-Barriga, F., \& Monroy, M. (2004). Arsenic and heavy metal pollution of soil, water and sediments in a semi-arid climate mining area in Mexico. Water, Air, and Soil Pollution, 152, 129-152.

https://doi.org/10.1023/B:WATE.0000015350.14520.c1

RStudio Team. (2020). RStudio: Integrated development environment for R. Boston, MA. http://www.rstudio.com

Sarma, K. (2002). Coal mining and its impact on environment of Nokrek biosphere reserve, Meghalaya $[\mathrm{PhD}$ thesis, Department of Geography, North Eastern Hill University, Shillong]. https://shodhganga.inflibnet.ac.in/handle/10603/60712

Sharma, K. L., Mandal, U. K., Srinivas, K., Vittal, K. P. R., Mandal, B., Grace, J. K., \& Ramesh, V. (2005). Long-term soil management effects on crop yields and soil quality in a dryland Alfisol. Soil and Tillage Research, 83(2), 246-259. https://doi.org/10.1016/j.still.2004.08.002

Talukdar, B., Kalita, H. K., Basumatary, S., \& Sarma, D. (2016). Impact of coal mining on soil characteristics of Simsang river, Meghalaya, India. Journal of Fundamental of Renewable Energy, 6(6), 45-86.

Tapadar, S. A., \& Jha, D. K. (2015). Influence of open cast mining on the soil properties of Ledo Colliery of Tinsukia district of Assam, India. International Journal of Scientific and Research Publications, 5(3), 1-4.

Thomilson, D. C., Wilson, D. J., Harris, C. R., \& Jeffrey, D. W. (1980). Problem in heavy metals in estuaries and the formation of pollution index. Helgolander Meeresunters, 33, 566575. https://doi.org/10.1007/BF02414780

Triantafyllidis, V., Kosma, A. K. C., \& Patakas, A. (2018). An assessment of the soil quality index in a Mediterranean agro ecosystem. Emirates Journal of Food and Agriculture, 30(12), 1042-1050. https://doi.org/10.9755/ejfa.2018.v30.i12.1886

Trivedy, R. K., \& Goel, P. K. (1986). Chemical and biological methods for water pollution studies. Environmental Publication. Karad.

Vasu, D., Singh, S. K., Ray, S. K., Duraisami, V. P., Tiwary, P., Chandran, P., Nimkar, A. M., \& Anantwar, S. G. (2016). Soil quality index (SQI) as a tool to evaluate crop productivity in semi-arid Deccan plateau, India. Geoderma, 282, 70-79. https://doi.org/10.1016/j.geoderma.2016.07.010

Walkley, A., \& Armstrong Black, I. (1934). An examination of the Degtjareff method for determining soil organic matter, and a proposed modification of the chromic acid titration method. Soil Sciences, 37(1), 29-38. https://doi.org/10.1097/00010694-193401000-00003

Yu, P. J., Liu, S. W., Zhang, L., Li, Q., \& Zhou, D. W. (2018). Selecting the minimum data set and quantitative soil quality indexing of alkaline soils under different land uses in northeastern China. Science of the Total Environment, 616, 564-571. https://doi.org/10.1016/j.scitotenv.2017.10.301 